\title{
Potencjał wykorzystania współpracy międzygminnej w gospodarowaniu odpadami komunalnymi z perspektywy gmin kujawsko-pomorskich i wielkopolskich
}

\author{
Potential for applying inter-municipal cooperation in the area \\ of solid waste management from the perspective of the local \\ governments in Kuyavian-Pomeranian and Greater Poland \\ Voivodeships
}

\section{Streszczenie:}

Artykuł traktuje o motywach podejmowania współpracy przez polskie gminy w gospodarce odpadami komunalnymi oraz o korzyściach z takiego współdziałania. Bazuje na analizie uwarunkowań gospodarki odpadami po tzw. reformie śmieciowej z 2013 roku oraz na wynikach ankiety przeprowadzonej w kujawsko-pomorskich i wielkopolskich urzędach gmin. Ankieta wykazała, że współpracę najczęściej podejmowano w celu spełnienia wymogów prawnych, realizacji wspólnej inwestycji lub obniżenia kosztów. W większości przypadków osiągnięto zakładane efekty współdziałania, a jego przebieg oceniono pozytywnie.

Słowa kluczowe: współpraca międzygminna, gospodarka odpadami komunalnymi

\begin{abstract}
:
This article touches on the issue of identifying motives for inter-municipal cooperation in the area of solid waste management in Poland, as well as the benefits for local governments from this cooperation. It is based on the analysis of the solid waste management conditions and on the survey of municipalities' offices. According to the survey,
\end{abstract}


Aleksandra Picej - Potencjał wykorzystania współpracy międzygminnej...

the municipalities enter cooperation most frequently in order to meet the legal requirements, make common investments, or reduce costs. In most cases the municipalities have achieved their goals and positively evaluated cooperation.

Keywords: inter-municipal cooperation, solid waste management

\section{Wprowadzenie}

Pomimo że obowiązujące podziały terytorialne z założenia powinny sprzyjać sprawnemu działaniu państwa i samorządów ${ }^{1}$, w praktyce niemożliwe jest wyznaczenie granic, które odpowiadałyby wszystkim obszarom funkcjonalnym. Niepokrywanie się administracyjnych jednostek z optymalnym zasięgiem świadczenia niektórych usług publicznych skłania samorządy do poszukiwania alternatywnych (i dopuszczalnych w ramach obowiązującego prawa) sposobów ich dostarczania, takich jak np. wspólne wykonywanie wybranych zadań przez kilka gmin ${ }^{2}$.

Spodziewane wyraźne korzyści skali w gospodarce odpadami komunalnymi stwarzają potencjał dla wykorzystania współpracy międzygminnej w tej dziedzinie. 0 dużej roli i powszechności tego narzędzia świadczą liczne prace europejskich badaczy, analizujące jego finansową opłacalnośćs . Większość z nich wskazuje, że współdziałanie w gospodarce odpadami wiąże się z oszczędnościami dla gmin ${ }^{4}$. Na gruncie polskim takie badania nie były dotychczas prowadzone, jednak z inwentaryzacji form współpracy międzygminnej dokonanych m.in. przez Bartłomieja

${ }^{1}$ D. Ilnicki, T. Siłka, Polska przestrzeń w kontekście nowego podziału administracyjnego, [w:] H. Rogacki (red.), Koncepcje teoretyczne i metody badań geografii społeczno-ekonomicznej i gospodarki przestrzennej, Poznań 2001, s. 293.

${ }^{2}$ G. Bel, X. Fageda, M. Mur, Does Cooperation Reduce Service Delivery Costs? Evidence from Residential Solid Waste Services, „Journal of Public Administration Research and Theory" 2014, nr 24, s. 85-86. Wśród innych możliwych rozwiązań, niebędących przedmiotem niniejszego artykułu, autorzy wymieniają zmianę istniejącego podziału terytorialnego lub zlecenie wybranych zadań zewnętrznym podmiotom (outsourcing).

${ }^{3}$ Wykaz wybranych publikacji zamieszczono w bibliografii na końcu niniejszego artykułu.

${ }^{4}$ Zestawienia wyników badań w tym zakresie dokonali m.in. Bel i Warner [w:] G. Bel, M. Warner, Inter-municipal cooperation and costs: Expectation and evidence, „Public Administration" 2015, nr 93(1), s. 52-67. 
Kołsuta $^{5}$ oraz Pawła Swianiewicza ${ }^{6}$ wraz z zespołem wynika, że polskie samorządy lokalne również współdziałają w tej dziedzinie.

Niniejszy artykuł poświęcony jest rozważaniom na temat motywów podejmowania współpracy przez gminy w gospodarce odpadami komunalnymi w Polsce. Jego głównym celem jest sprawdzenie, które z ugruntowanych w teorii przesłanek ku współdziałaniu mają znaczenie $\mathrm{w}$ rzeczywistości oraz $\mathrm{w}$ jakim stopniu oczekiwania gmin co do efektów współpracy są spełnione. Badanie oparto na analizie uwarunkowań gospodarki odpadami komunalnymi w Polsce pod kątem potencjalnego zapotrzebowania na współpracę w tej dziedzinie oraz na wynikach ankiety przeprowadzonej z pracownikami urzędów gmin kujawsko-polskich i wielkopolskich ${ }^{7}$.

\section{Wprowadzenie do współpracy międzygminnej. Dlaczego gminy współpracują?}

W ogólnym ujęciu współpraca zachodzi wówczas, gdy co najmniej dwa podmioty w sposób świadomy razem podejmują działania, mające służyć zrealizowaniu wspólnego celu, zwykle trudnego do osiągnięcia samodzielnie. W kontekście współpracy międzygminnej tymi podmiotami są gminy, które razem wykonują wybrane zadania lub realizują wspólne przedsięwzięcia. W zależności od obowiązujących regulacji prawnych współdziałanie samorządów lokalnych może przybierać różne formy, jednak z zasady jest ono dobrowolne i nie powoduje pełnego przekazania przez gminę jej kompetencji innym podmiotom ${ }^{8}$ Może za-

${ }^{5}$ B. Kołsut, Zinstytucjonalizowane sieci współdziałania międzygminnego w Polsce, Poznań 2015, s. 111.

${ }^{6}$ P. Swianiewicz, A. Gendźwiłł, J. Krukowska, M. Lackowska, A. Picej, Współpraca międzygminna w Polsce. Zwiq̨zek z rozsq̨dku, Warszawa 2016, s. 100.

${ }^{7}$ Kwestionariusz rozesłano do urzędów wszystkich gmin (144 kujawsko-pomorskich i 226 wielkopolskich) pocztą elektroniczną na początku 2017 roku, z prośbą o skierowanie go do osób zajmujących się sprawami gospodarki odpadami komunalnymi. Do końca marca otrzymano wypełnione ankiety od 185 gmin, co oznacza zwrot na poziomie $50 \%$.

${ }^{8}$ P. Swianiewicz, Demanded but Difficult: Intermunicipal Cooperation in Central and Eastern Europe, [w:] P. Swianiewicz (red.) Working Together. Intermunicipal Cooperation in Five Central European Countries, Budapest 2011, s. 3. 
Aleksandra Picej - Potencjał wykorzystania współpracy międzygminnej...

tem stanowić subtelniejszą alternatywę dla łączenia gmin i zmian granic administracyjnych, ponieważ stwarza jednostkom podobne szanse usprawnienia ich funkcjonowania przy jednocześnie mniejszej ingerencji w ich niezależność 9 .

Najbardziej uniwersalną przyczyną współdziałania gmin jest wyeksponowana we wstępie niniejszego artykułu niedoskonałość zasadniczego terytorialnego podziału państwa, powodująca niepokrywanie się granic samorządowych jednostek $\mathrm{z}$ zasięgami funkcjonalnymi ${ }^{10}$. Zjawisko to uwidacznia się w różny sposób. Z jednej strony może dotyczyć aspektów finansowych, gdy optymalny ekonomicznie zasięg wykonywania niektórych zadań wykracza znacząco poza terytoria gmin. Możliwość osiągnięcia korzyści skali i podziału kosztów między kilku partnerów uzasadnia w tej sytuacji podjęcie współpracy (np. w celu wspólnej realizacji, a następnie eksploatacji dużej inwestycji, poprawy jakości świadczonych usług lub zredukowania wydatków ponoszonych przez każdą z gmin). Z drugiej strony podstawą wyodrębnienia przestrzeni funkcjonalnej mogą być także powiązania funkcjonalne między tworzącymi ją samorządami. Ich źródło stanowią zazwyczaj specyficzne uwarunkowania panujące na danym terenie, wynikające np. z położenia w kotlinie górskiej, dolinie rzeki lub w pobliżu dużego ośrodka miejskiego silnie oddziałującego na otoczenie. W tym kontekście współpraca umożliwia skoordynowanie kwestii wpływających na cały obszar funkcjonalny (np. ochrony środowiska, organizacji transportu publicznego $\mathrm{w}$ aglomeracji) i podjęcie związanych z nimi działań, których realizacja przez pojedyncze gminy nie byłaby wystarczająco skuteczna.

Różnorodność zastosowań współpracy międzygminnej stwarza możliwość wyodrębnienia bardziej szczegółowych przyczyn jej podejmowania, które doczekały się w literaturze licznych klasyfikacji ze

\footnotetext{
${ }^{9}$ R. Hulst, A. van Montfort (red.), Inter-municipal Cooperation in Europe, Dordrecht 2007, s. 8-9. Argument ten jest szczególnie istotny w państwach, w których samorząd lokalny istnieje stosunkowo krótko i wszelkie próby odgórnej ingerencji w istniejący układ terytorialny mogą być postrzegane jako „zagrożenie” dla samorządności i zapowiedź dalszych reform - por. R. Hulst, A. van Montfort (red.), Inter-municipal Cooperation..., op. cit., s. 233.

${ }^{10}$ H.R. Baker 1993 za: M. Furmankiewicz, Funkcjonalno-przestrzenne sieci współpracy samorządów lokalnych, „Studia Regionalne i Lokalne” 2002, nr 1(8), s. 11.
} 
względu na różne kryteria ${ }^{11}$. Niniejszy artykuł odwołuje się do trzech zasadniczych grup motywów wydzielonych przez Helen Sullivan i Chrisa Skelchera ${ }^{12}$. Autorzy pisali o nich w odniesieniu do partnerstw międzysektorowych, jednak prace innych badaczy wskazują na to, że owa typologia znajduje zastosowanie również $\mathrm{w}$ analizie przyczyn podejmowania współpracy międzygminnej ${ }^{13}$. W nawiązaniu do koncepcji Sullivan i Skelchera współdziałanie samorządów lokalnych może być zatem przejawem:

- ich dążenia do osiągnięcia wspólnego celu,

- próby zachowania przez nie obecnego status quo,

- ich reakcji na zmieniające się warunki zewnętrzne ${ }^{14}$.

Powyższe grupy motywów nie są rozłączne i nierzadko równocześnie oddziałują na decyzje władz lokalnych o podjęciu współpracy ${ }^{15}$. 0 ile jednak dążenie do osiągnięcia wspólnego celu jest intuicyjnie zrozumiałe i może dotyczyć wszystkich sfer działalności samorządów lokalnych, o tyle dwie pozostałe kategorie wymagają komentarza.

Współdziałanie gmin służące zachowaniu przez nie obecnego status quo zwykle dotyczy krajów o dużej fragmentacji terytorialnej, w których rozważane są reformy zmierzające do łączenia zbyt małych gmin, niezdolnych do samodzielnego, efektywnego funkcjonowania. Współpraca ma umożliwić osiągnięcie efektów postulowanych przez zwolenników reformy (przede wszystkim korzyści skali), ale bez ingerencji $\mathrm{w}$ istniejące granice administracyjne. W Polsce motyw ten ma raczej niewielkie znaczenie, jako że odgórne scalanie niedużych jednostek samorządowych nie jest obecnie procedowane ${ }^{16}$.

Zdecydowanie bardziej prawdopodobne na gruncie polskim wydaje się podjęcie współpracy międzygminnej w reakcji na zmieniające się

\footnotetext{
${ }^{11}$ Por.: M. Furmankiewicz, Funkcjonalno-przestrzenne sieci..., op. cit., s. 9.

${ }^{12}$ H. Sullivan, C. Skelcher, Working across boundaries: collaboration in public services, Basingstoke 2002, s. 36.

${ }^{13}$ P. Swianiewicz, A. Gendźwiłł, J. Krukowska, M. Lackowska, A. Picej, Współpraca międzygminna..., op. cit.

${ }^{14}$ H. Sullivan, C. Skelcher, Working across..., op. cit., s. 36.

${ }^{15}$ P. Swianiewicz, A. Gendźwiłł, J. Krukowska, M. Lackowska, A. Picej, Współpraca międzygminna..., op. cit., s. 22.

${ }^{16}$ Ibidem, s. 20.
} 
Aleksandra Picej - Potencjał wykorzystania współpracy międzygminnej...

warunki zewnętrzne ${ }^{17}$. Katalog bodźców, które mogą stymulować takie współdziałanie jest rozległy. Obejmuje zarówno niespodziewane impulsy o rozmaitej genezie, jak i procesy inicjowane celowo przez różne instytucje. Do pierwszej grupy można zaliczyć np. kryzys ekonomiczny skłaniający gminy do kooperacji w celu wygenerowania oszczędności (poprzez korzyści skali) lub katastrofę naturalną (np. powódź), która jednoczy dotknięte nią samorządy w walce z jej skutkami. W drugiej kategorii zawierają się wszelkie działania rządu (czasem także szczebla unijnego lub regionalnego) mające stymulować współdziałanie. Współpraca, zwłaszcza w swojej początkowej fazie, wiąże się z pewnym organizacyjnym i finansowym wysiłkiem dla samorządów. Co więcej, jej podjęcie wiąże się nie tylko z korzyściami, ale też z ryzykiem wystąpienia kosztów transakcyjnych i niepożądanych skutków ubocznych typowych dla działań zbiorowych ${ }^{18}$. Powoduje to, że zwykle (zwłaszcza w państwach o niskim poziomie zaufania i kapitału społecznego) potrzebne są zewnętrzne zachęty do współpracy ${ }^{19}$. Najczęściej mają one pozytywny charakter i stwarzają dodatkowe możliwości kooperującym samorządom, np. w postaci dostępu do dodatkowych źródeł finansowania. Istnieją jednak również „zachęty negatywne”, takie jak realna perspektywa przeniesienia na wyższy szczebel samorządu części kompetencji jednostek, które wbrew zaleceniom rządu nie podejmą współdziałania. W takiej sytuacji granica między „dobrowolną” a „obowiązkową"20 kooperacją ulega zatarciu.

${ }^{17}$ Ibidem, s. 21-22.

${ }^{18}$ P. Swianiewicz, Demanded but Difficult..., op. cit., s. 8-10. Do najczęściej wymienianych negatywnych skutków ubocznych należą ograniczenie swobody decyzyjnej i niezależności władz lokalnych, spowolnienie procesu decyzyjnego, zmniejszenie przejrzystości działań w ramach kooperacji, a także wzrost kosztów administracyjnych (w przypadku duplikacji struktur w gminie i w instytucji współpracy).

${ }^{19}$ Ibidem, s. 16.

${ }^{20}$ W niektórych państwach (np. we Włoszech, Portugalii) istnieją przepisy zobowiązujące gminy (w określonych przypadkach) do współdziałania (zob. P. Swianiewicz, A. Gendźwiłł, J. Krukowska, M. Lackowska, A. Picej, Współpraca międzygminna..., op. cit., s. 21). Obligatoryjna współpraca nie jest jednak przedmiotem zainteresowania niniejszego artykułu, jako że żadna z polskich ustaw nie nakazuje gminom bezwzględnie podęcia współpracy. 
Warto zaznaczyć, że kooperacja może być także odpowiedzią na zmiany prawne niedotyczące bezpośrednio współpracy międzygminnej. Reforma ingerująca w funkcjonowanie samorządów może skłonić je do współdziałania w celu wspólnego wdrażania nowych regulacji i wspierania się $w$ tym procesie oraz wzajemnej nauki i wymiany doświadczeń. Przykładowo, poszerzenie zakresu dotychczasowych kompetencji gmin w obliczu ich niewystarczających dochodów może zintensyfikować potrzebę osiągnięcia korzyści skali i tym samym stać się impulsem do rozpoczęcia współpracy. Kooperacja ma szanse rozwinąć się również już na etapie przygotowywania nowej ustawy. Gminy chcąc, aby nowe prawo nie ograniczało zanadto ich swobody decyzyjnej oraz nie stwarzało barier dla ich sprawnego funkcjonowania, w celu wzmocnienia siły i roli ich opinii w debacie mogą się zjednoczyć i wspólnie lobbować wobec rządu na rzecz uwzględnienia ich postulatów w procesie legislacyjnym. Oczywiście wzmocnienie pozycji samorządów lokalnych (niezależnie od zmiany uwarunkowań) może stanowić zasadniczy cel współpracy międzygminnejej ${ }^{21}$, podobnie jak wzajemna wymiana doświadczeń i osiągnięcie korzyści skali.

Powyższe rozważania stanowią jedynie ogólne wprowadzenie do złożonej problematyki współpracy międzygminnej. Na decyzję o zainicjowaniu współdziałania, a także na jego dalszy rozwój i efekty wpływają jeszcze inne czynniki, takie jak np. relacje między władzami gmin i ich spójna wizja partnerstwa, tradycja współpracy i umiejętności w jej zakresie, a także sprzyjające współdziałaniu otoczenie prawne ${ }^{22}$. W niniejszym artykule uwagę skupiono na motywach gmin podejmujących współpracę w gospodarce odpadami w Polsce oraz na percepcji korzyści płynących z tejże kooperacji.

${ }^{21}$ P. Swianiewicz, A. Gendźwiłł, J. Krukowska, M. Lackowska, A. Picej, Współpraca międzygminna..., op. cit., s. 20.

${ }^{22}$ Council of Europe, Toolkit Manual Inter-municipal Cooperation, 2010, s. 25-32, http://www.municipal-cooperation.org/images/4/4c/IMC_Toolkit_Manual.pdf [dostęp: 1-07-2017]. 
Aleksandra Picej - Potencjał wykorzystania współpracy międzygminnej...

\section{Motywy współpracy międzygminnej w świetle uwarunkowań gospodarki odpadami komunalnymi w Polsce}

Znaczna część z przytoczonych motywów współpracy międzygminnej wydaje się trafna w odniesieniu do gospodarki odpadami komunalnymi w Polsce. W połowie 2013 roku, wraz z wejściem w życie nowelizacji Ustawy o utrzymaniu czystości i porządku w gminach $^{23}$, nastąpiła radykalna zmiana uwarunkowań prawnych. Samorządy gminne zostały zobowiązane do stworzenia kompleksowego systemu gospodarowania odpadami komunalnymi na ich terenie i do objęcia nim wszystkich właścicieli nieruchomości ${ }^{24}$. W porównaniu z dotychczasowym stanem legislacyjnym zakres ich zadań uległ znacznemu poszerzeniu ${ }^{25}$. W myśl ustawodawcy koszty ponoszone w związku z nowymi kompetencjami powinny zostać pokryte z opłat za gospodarowanie odpadami pobieranych przez gminy od właścicielu nieruchomości ${ }^{26}$. Pomimo stworzenia możliwości pozyskania dodatkowych dochodów, wprowadzenie w życie założeń reformy stanowiło niemałe obciążenie dla gminnych budżetów, zwłaszcza w fazie początkowej, zanim zasiliły je wpływy z opłat.

Zgodnie z przesłankami teoretycznymi, nieunikniony wzrost wydatków w połączeniu $\mathrm{z}$ dużym wysiłkiem organizacyjno-administracyjnym stwarza okoliczności sprzyjające rozpoczęciu przez gminy współdziałania. Niewykluczone, że część instytucji współpracy międzygminnej w gospodarce odpadami powstało $\mathrm{w}$ odpowiedzi na

\footnotetext{
${ }^{23}$ Dz.U. 1996 nr 132, poz. 622, z późn. zm.

${ }^{24}$ Dz.U. 1996 nr 132, poz. 622, z późn. zm., art. 3 ust. 2, pkt 2.

${ }^{25}$ Przed reformą właściciele nieruchomości zawierali indywidualne umowy z firmą odbierającą odpady. Władze lokalne w większości gmin pełniły głównie rolę regulatora rynku poprzez wydawanie zezwoleń przedsiębiorcom spełniającym odpowiednie warunki. Po wejściu w życie nowych przepisów to gminy pobierają od właścicieli nieruchomości opłaty za gospodarowanie odpadami i zlecają podmiotowi (w drodze przetargu lub bezprzetargowo w przypadku spełnienia kryteriów dla tzw. in-house) świadczenie tej usługi w swoich granicach. Zmiana ta jest obligatoryjna w odniesieniu do nieruchomości zamieszkałych; objęcie systemem również nieruchomości niezamieszkałych jest dobrowolne. „Reforma śmieciowa” nałożyła na samorządy gminne jeszcze szereg innych obowiązków, m.in. z zakresie działalności regulacyjnej i sprawozdawczej - więcej na ten temat w: J. Jerzmański, Gospodarka odpadami komunalnymi nowe zasady, „Przegląd Komunalny” 2011, nr 9 (240), s. 83-98.

${ }^{26}$ Dz.U. 1996 nr 132, poz. 622, z późn. zm., art. 6r ust. 2.
} 
zmianę uwarunkowań prawnych ${ }^{27}$ i chęć wspólnego wypracowania jak najlepszych rozwiązań, w tym obniżenia kosztów przy jednoczesnym zachowaniu wysokiej jakości wykonywanych zadań. Dążenie do zmniejszenia wydatków ponoszonych przez poszczególne gminy można przy tym rozpatrywać dwutorowo; po pierwsze jako obniżanie bieżących kosztów jednostkowych świadczenia usługi (dzięki korzyściom skali), a po drugie jako podział wydatków między partnerów realizujących wspólnie dużą inwestycję (np. zakład przetwarzania odpadów).

Współpraca w gospodarowaniu odpadami może służyć także realizacji formalnych wymogów wyrażonych w znowelizowanej ustawie, takich jak minimalna liczba ludności obsługiwana przez regionalną instalację do przetwarzania odpadów komunalnych (RIPOK). Jeśli zostało zapisane to w wojewódzkim planie gospodarki odpadami (WPGO), gminy są zobowiązane do zapewnienia (samodzielnie lub z innymi gminami) budowy, utrzymania i eksploatacji RIPOK ${ }^{28}$, przy czym jednym z warunków uzyskania przez instalację statusu RIPOK jest obsługa przez nią co najmniej 120 tys. mieszkańców ${ }^{29}$. Stanowi to przykład zewnętrznej „zachęty" do współpracy, ponieważ zdecydowana większość gmin nie jest w stanie spełnić tego wymogu w pojedynkę. Przytoczony przepis świadczy również o dążeniu ustawodawcy do skłonienia gmin do prowadzenia gospodarki odpadami w racjonalnej ekologicznie i jednocześnie opłacalnej ekonomicznie skali, wykraczającej poza granice przeciętnych jednostek gminnych w Polsce. Służą temu też regiony gospodarki odpadami komunalnymi wyznaczane w WPGO dla obszarów zamieszkanych przez co najmniej 150 tys. mieszkańców ${ }^{30}$. Z perspektywy niniejszej analizy są one istotne, ponieważ dotyczące ich ustalenia są wiążące dla gmin i stanowią istotne ramy dla współpracy. Warto podkreślić, że WPGO są sporządzane przez samorządy województw i podlegają jedynie

\footnotetext{
${ }^{27}$ Analiza dynamiki tworzenia związków międzygminnych dokonana przez Swianiewicza wraz z zespołem wykazała, że w latach 2010-2014 (a więc w okresie przygotowań do reformy oraz jej wdrażania) powstało aż 14 związków deklarujących działalność w dziedzinie gospodarki odpadami (P. Swianiewicz, A. Gendźwiłł, J. Krukowska, M. Lackowska, A. Picej, Współpraca międzygminna..., op. cit., s. 100).

${ }^{28}$ Dz.U. 1996 nr 132 poz. 622, z późn. zm., art. 3 ust. 1, pkt 2.

${ }^{29}$ Ibidem, art. 35 ust. 6.

${ }^{30}$ Ibidem, art. 35 ust. 5.
} 
Aleksandra Picej - Potencjał wykorzystania współpracy międzygminnej...

zaopiniowaniu przez gminy ${ }^{31}$. Stwarza to przestrzeń dla współdziałania gmin w celu wypracowania wspólnego stanowiska wobec ustaleń wojewódzkich oraz wzmocnienia roli ich opinii w tym procesie.

Chęć zwiększenia widoczności postulatów samorządów lokalnych związanych z gospodarką odpadami komunalnymi może dotyczyć również areny krajowej. Od momentu reformy w 2013 roku regulacje prawne w tym zakresie były kilkakrotnie zmieniane. Modyfikacje przepisów w mniejszym lub większym stopniu powodują konieczność dostosowywania istniejących gminnych systemów gospodarki odpadami do nowych wymogów. Gminy, chcąc aby wprowadzane zmiany były zgodne z ich potrzebami i oczekiwaniami, mogą wspólnie, w ramach współpracy, lobbować w tym celu.

Powyższy przegląd uwarunkowań gospodarki odpadami komunalnymi w Polsce wskazuje na istnienie bodźców mogących stymulować kooperację gmin $w$ tej dziedzinie. Ponieważ jednak współpraca samorządów lokalnych jest złożonym zjawiskiem, zależnym od różnorodnych czynników nieanalizowanych w niniejszym artykule, opisane przesłanki nie gwarantują jej podjęcia. W dalszej części opracowania przedstawiono wyniki badania opinii urzędów gmin na temat potrzeby współdziałania w gospodarce odpadami oraz jego motywów i efektów.

\section{Współpraca międzygminna w gospodarowaniu odpadami w opinii wielkopolskich i kujawsko pomorskich urzędów gmin}

W celu porównania wniosków płynących z teoretycznych rozważań z rzeczywistym podejściem polskich samorządów lokalnych do współpracy międzygminnej w gospodarce odpadami przeprowadzono badanie ankietowe. Badaniem objęto wszystkie gminy województwa kujawsko-pomorskiego (144) i wielkopolskiego (226). Do końca marca 2017 roku otrzymano wypełnione ankiety od 185 gmin, co oznacza zwrot na poziomie $50 \%$. Odpowiedzi gmin kujawsko-pomorskich stanowiły $36 \%$, zaś wielkopolskich $64 \%$ wszystkich nadesłanych formularzy,

\footnotetext{
${ }^{31}$ Ibidem, art. 36 ust 4.
} 
zatem w przybliżeniu zachowano proporcje charakteryzujące wyjściową próbę badawczą. W 70\% przypadków ankieta została wypełniona przez osobę pracującą na stanowisku urzędniczym do spraw gospodarki odpadami. Prawie wszyscy pozostali respondenci także byli urzędnikami, jednak z inaczej zdefiniowanym zakresem działalności (np. ochrona środowiska, gospodarka komunalna).

Spośród gmin, które wzięły udział w badaniu, jedna trzecia zadeklarowała współpracę $\mathrm{z}$ innymi gminami w odbiorze lub zagospodarowaniu odpadów komunalnych. Ponad połowa z nich to członkowie związków międzygminnych, zaś kolejne 30\% to uczestnicy porozumień. Pozostałe 15\% stanowili udziałowcy spółek międzykomunalnych działających w gospodarce odpadami ${ }^{32}$. Tylko jeden respondent odpowiedział, że reprezentowana przez niego gmina współdziała w dwóch formach jednocześnie, a mianowicie w związku i spółce.

Pierwsza część pytań służyła poznaniu ogólnych opinii respondentów o przepisach regulujących gospodarkę odpadami (wykres 1). Zdecydowana większość ankietowanych zgodziła się ze stwierdzeniem, że obowiązujące prawo stwarza gminom warunki i narzędzia umożliwiające efektywną gospodarkę odpadami. Jednocześnie prawie jedna czwarta była przeciwnego zdania, co wskazuje, że dość duża grupa samorządów widzi potrzebę udoskonalenia istniejących przepisów i może być skłonna do poszukiwania alternatywnych sposobów wykonywania zadań w tym zakresie. $W$ tym kontekście istotne wydaje się pytanie o swobodę gmin w kształtowaniu ich systemów gospodarki odpadami. Ponad 30\% respondentów uznało, że jej zakres jest niewystarczający, przy czym dwukrotnie więcej z nich odpowiedziało, że jest on dostateczny. Równocześnie, prawie trzy czwarte przedstawicieli urzędów przyznało, że na organizację gospodarki odpadami komunalnymi

${ }^{32}$ Lista ta nie wyczerpuje wszystkich form prawnych współpracy polskich gmin, jednak tylko te pojawiły się w odpowiedziach udzielonych w ankiecie. Przedmiotem niniejszego artykułu nie jest analiza form prawnych współpracy, jednak warto podkreślić, że poprzez porozumienia, związki i spółki możliwe jest wykonywanie zadań publicznych, w przeciwieństwie do np. stowarzyszeń, które nie są do tego uprawnione. Pełny przegląd i charakterystykę form współdziałania gmin w Polsce można znaleźć m.in. w: P. Swianiewicz, A. Gendźwiłł, J. Krukowska, M. Lackowska, A. Picej, Współpraca międzygminna..., op. cit., s. 59-70. 
Aleksandra Picej - Potencjał wykorzystania współpracy międzygminnej...

w ich gminie znacząco wpływają decyzje szczebla wojewódzkiego. Zestawienie tych odpowiedzi pozwala zatem przypuszczać, że postanowienia samorządów województw, pomimo ich silnego oddziaływania, nie stanowią dla większości gmin ograniczenia ich swobody.

Wykres 1. Ogólne opinie urzędów gmin na temat przepisów regulujących gospodarkę odpadami

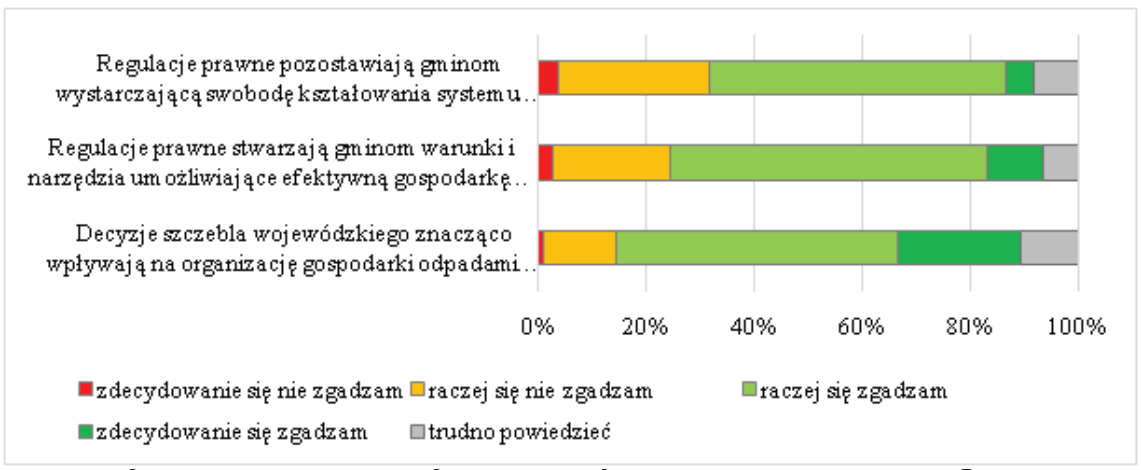

W ogólnym ujęciu przeważająca część badanych pozytywnie oceniła otoczenie prawne gospodarki odpadami, jednak omówione wyniki wskazują, że spora grupa (ok. 30\%) ma do nich zastrzeżenia. W takich okolicznościach współpraca międzygminna mogłaby posłużyć zwiększeniu widoczności gmin i wzmocnieniu ich głosu w dyskusji nad regulacjami prawnymi, a być może nawet bezpośrednio przyczynić się do usprawnienia gospodarki odpadami komunalnymi w gminach. Czy zatem w opinii ankietowanych kooperacja jest potrzebna?

Prawie połowa respondentów zgodziła się ze stwierdzeniem, że „reforma śmieciowa" z 2013 roku spowodowała wzrost zapotrzebowania na współpracę międzygminną w zagospodarowaniu odpadów. W przypadku odbioru odpadów taki pogląd wyraziło ponad 30\% urzędów gmin. Według pozostałych reforma nie wpłynęła znacząco na kooperację w tej dziedzinie, choć pojawiły pojedyncze głosy sugerujące spadek zapotrzebowania na współdziałanie. Odpowiedzi na pytanie o to, czy współpraca międzygminna jest niezbędna dla efektywnego systemu 
gospodarki odpadami, istotnie różniły się w grupie gmin współdziałających i niewspółdziałających (wykres 2). 0 ile reprezentanci tych pierwszych częściej (w ok. 75\%) i pewniej (duży odsetek „zdecydowanych wskazań") odpowiadali pozytywnie, o tyle reakcje urzędów gmin niewspółpracujących były podzielone.

Wykres 2. Opinie urzędów gmin na temat zapotrzebowania na współpracę w gospodarce odpadami

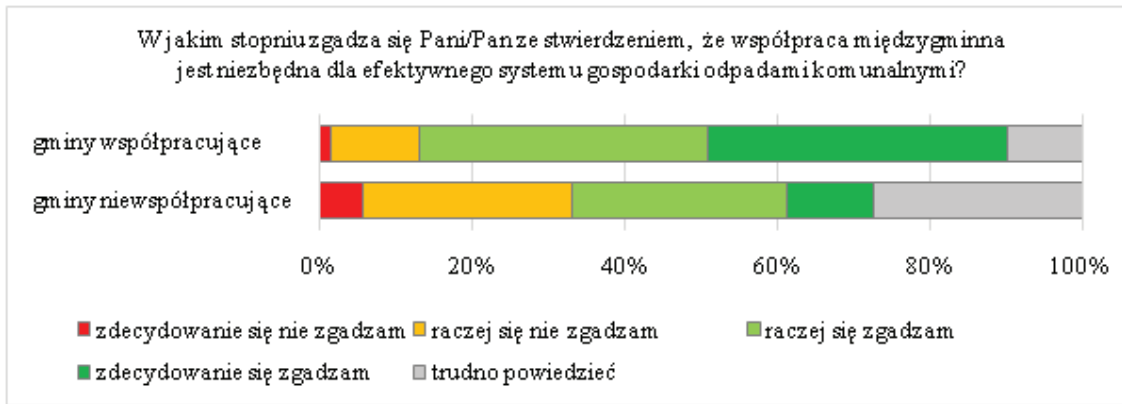

Dużo wyraźniejszy obraz wyłonił się z odpowiedzi na kolejne pytanie. Spośród 185 gmin, które wzięły udział w ankiecie, 107 nigdy nie współdziałało w tej dziedzinie, z czego prawie wszystkie jako główną przyczynę wymieniły „brak potrzeby współpracy”. W pojedynczych przypadkach respondenci nawiązywali do ryzyka wystąpienia negatywnych skutków ubocznych działań zbiorowych, takich jak zmniejszenie przejrzystości działań i procesów decyzyjnych oraz ograniczenie niezależności gminy. Kilku ankietowanych wskazało też na przepisy prawne utrudniające kooperację oraz na ograniczające swobodę jej kształtowania postanowienia samorządu województwa. Co więcej te dwie ostatnie okoliczności wymieniane były także jako główne przyczyny zaprzestania kooperacji przez gminy, które kiedyś współpracowały. Również ponad 30\% gmin obecnie współdziałających zgodziło się z tym, że obowiązujące przepisy „utrudniają" współpracę; jednocześnie zbliżony odsetek nie potrafił ustosunkować się do tego stwierdzenia i wybrał odpowiedź „trudno powiedzieć”. 
Aleksandra Picej - Potencjał wykorzystania współpracy międzygminnej...

Biorąc pod uwagę powyższe opinie warto przyjrzeć się bliżej motywom gmin, które zdecydowały się na zainicjowanie współdziałania w gospodarce odpadami (wykres 3). Ankieta wykazała, że ponad 70\% samorządów lokalnych objętych badaniem podjęło współpracę, aby wspólnie zrealizować inwestycję lub spełnić formalne wymogi prawne. Warto podkreślić, że motywy te mogły być ze sobą powiązane, np. jeśli realizowaną inwestycją była RIPOK, do której utworzenia gminy zobowiązuje ustawa. Wspólna inwestycja pośrednio łączy się również z innymi powodami, dla których gminy współpracują, tj. z potrzebą obniżenia kosztów świadczenia usług odbioru i zagospodarowania odpadów oraz wzmocnienia ochrony środowiska (2/3 odpowiedzi ankietowanych), a także z chęcią poprawy jakości usług i próbą zwiększenia szans na pozyskanie zewnętrznego dofinansowania (w ponad połowie badanych przypadków). Znacznie rzadziej przystąpienie samorządu do partnerstwa było podyktowane chęcią uzyskania dostępu do istniejącej infrastruktury technicznej będącej w posiadaniu innej gminy lub grupy gmin (mniej niż 30\% wskazań).

Wykres 3. Najważniejsze według respondentów motywy podejmowania współpracy międzygminnej w gospodarce odpadami

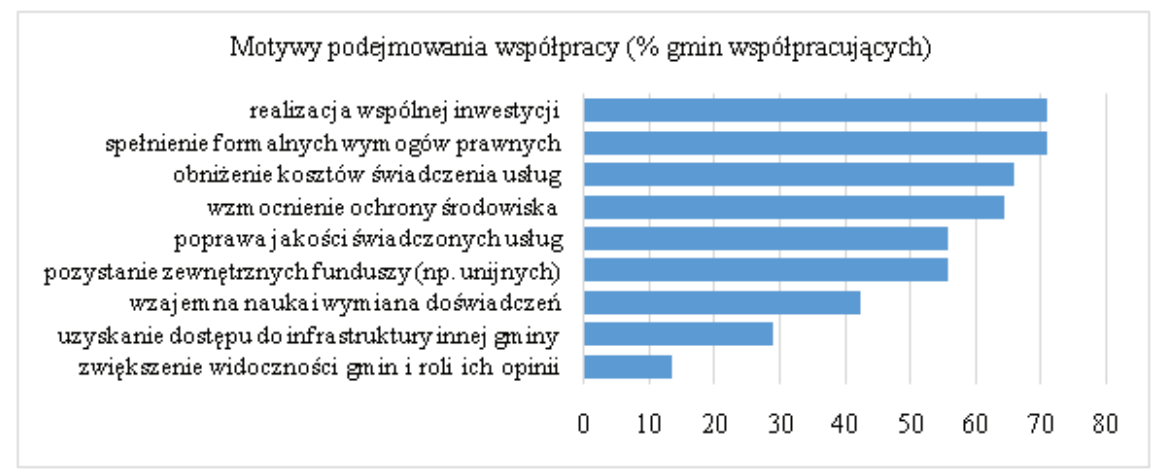

Źródło: opracowanie własne na podstawie wyników badania ankietowego.

Z wykresu 3 wynika ponadto, że motywy niezwiązane ściśle z wykonywaniem zadań z zakresu gospodarowania odpadami odegrały wyraźnie mniejszą rolę we wchodzeniu we współpracę. Chęcią wzajemnej 
nauki i wymiany doświadczeń kierowało się niewiele ponad $40 \%$ ankietowanych, zaś szansy na zwiększenie widoczności gmin i roli ich opinii na arenie krajowej i regionalnej upatrywało we współdziałaniu jedynie 14\% respondentów.

Dokonawszy analizy kluczowych motywów współpracy, warto przyjrzeć się korzyściom, jakie gminom przyniosła dotychczasowa kooperacja. Zestawienie deklarowanych powodów współdziałania z jego pozytywnymi efektami dostrzeżonymi przez respondentów zamieszczono w tabeli 1.

Tabela 1. Zestawienie odpowiedzi urzędów gmin na temat motywów współpracy i płynących z niej korzyści

\begin{tabular}{|l|l|l|l|}
\hline $\begin{array}{l}\text { Motyw podjęcia współpracy / } \\
\text { osiągnięta korzyść }\end{array}$ & $\begin{array}{l}\text { Cel zaplanowany } \\
\text { i zrealizowany }\end{array}$ & $\begin{array}{l}\text { Nieplanowana, } \\
\text { dodatkowa } \\
\text { korzyść }\end{array}$ & $\begin{array}{l}\text { Niespełnione } \\
\text { oczekiwania }\end{array}$ \\
\hline $\begin{array}{l}\text { spełnienie formalnych } \\
\text { wymogów prawnych }\end{array}$ & $39(90,7 \%)$ & $1(2,3 \%)$ & $3(7,0 \%)$ \\
\hline realizacja wspólnej inwestycji & $38(84,4 \%)$ & $3(6,7 \%)$ & $4(8,9 \%)$ \\
\hline $\begin{array}{l}\text { wzmocnienie ochrony } \\
\text { środowiska }\end{array}$ & $29(76,3 \%)$ & $0(0 \%)$ & $9(23,7 \%)$ \\
\hline $\begin{array}{l}\text { pozyskanie zewnętrznych } \\
\text { funduszy (np. unijnych) }\end{array}$ & $28(73,7 \%)$ & $5(13,2 \%)$ & $5(13,2 \%)$ \\
\hline $\begin{array}{l}\text { poprawa jakości } \\
\text { świadczonych usług }\end{array}$ & $27(61,4 \%)$ & $11(25 \%)$ & $6(13,6 \%)$ \\
\hline $\begin{array}{l}\text { obniżenie kosztów } \\
\text { świadczenia usług }\end{array}$ & $24(57,1 \%)$ & $3(7,1 \%)$ & $15(35,7 \%)$ \\
\hline $\begin{array}{l}\text { wzajemna nauka i wymiana } \\
\text { doświadczeń }\end{array}$ & $23(56,1 \%)$ & $16(39 \%)$ & $2(4,9 \%)$ \\
\hline $\begin{array}{l}\text { uzyskanie dostępu } \\
\text { do infrastruktury innej gminy }\end{array}$ & $11(47,8 \%)$ & $6(26,1 \%)$ & $6(26,1 \%)$ \\
\hline $\begin{array}{l}\text { zwiększenie widoczności } \\
\text { gmin i roli ich opinii }\end{array}$ & $4(33,3 \%)$ & $4(33,3 \%)$ & $4(33,3, \%)$ \\
\hline $\begin{array}{l}\text { Podsumowanie } \\
\text { dla wszystkich motywów }\end{array}$ & $223(68,4 \%)$ & $49(15,0 \%)$ & $54(16,6 \%)$ \\
\hline
\end{tabular}

Źródło: opracowanie własne na podstawie wyników badania ankietowego. 
Aleksandra Picej - Potencjał wykorzystania wspótpracy międzygminnej...

Największą zgodność motywów i korzyści odnotowano w zakresie spełnienia formalnych wymogów prawnych oraz realizacji wspólnej inwestycji. W około trzech czwartych przypadków efekty w postaci wzmocnienia ochrony środowiska oraz pozyskania zewnętrznych funduszy również były zbieżne z oczekiwaniami. Jednocześnie prawie $25 \%$ gmin deklarujących chęć poprawy ochrony środowiska poprzez współpracę nie udało się osiągnąć tego celu. Podobny poziom niespełnionych zamierzeń zaobserwowano $\mathrm{w}$ odniesieniu do motywu uzyskania dostępu do infrastruktury będącej własnością innego samorządu (lub grupy samorządów), przy czym w tym przypadku odnotowano równie wysoki odsetek nieplanowanych w momencie inicjowania współdziałania korzyści. Duży udział niespodziewanych dodatnich efektów zauważono także w poprawie jakości świadczenia usług w gospodarce odpadami. Najczęstszymi, pozytywnymi „skutkami ubocznymi” współdziałania okazały się wzajemna nauka i wymiana doświadczeń (prawie $40 \%$ wskazań).

Najwięcej niespełnionych oczekiwań pojawiło się w związku z motywem obniżenia kosztów świadczenia usług (ponad 35,7\% odpowiedzi). W niektórych gminach (choć nie we wszystkich) brak zakładanych oszczędności mógł łączyć się z niespodziewanym wzrostem jakości. Zbliżony poziom niezrealizowanych celów odnotowano także w przypadku zwiększenia widoczności samorządów lokalnych i roli ich opinii. Mały udział tego motywu w ogóle odpowiedzi w połączeniu z ich dużym zróżnicowaniem nie pozwala jednak na wyciąganie jakichkolwiek wniosków.

Uwzględniając opinie respondentów, kooperacja gmin w gospodarce odpadami wydaje się opłacalna. Niezrealizowane oczekiwania stanowiły łącznie nieco ponad $16 \%$ odpowiedzi, tj. niewielki odsetek w porównaniu z prawie $70 \%$ wskazań dla spełnionych motywów oraz $15 \%$ dla dodatkowych korzyści. Co więcej niemal wszyscy ankietowani zadeklarowali, że władze reprezentowanej przez nich gminy są zadowolone ze współpracy i jej efektów (wykres 4). 
Wykres 4. Opinie respondentów na temat zadowolenia władz gmin ze współpracy oraz na temat jej opłacalności

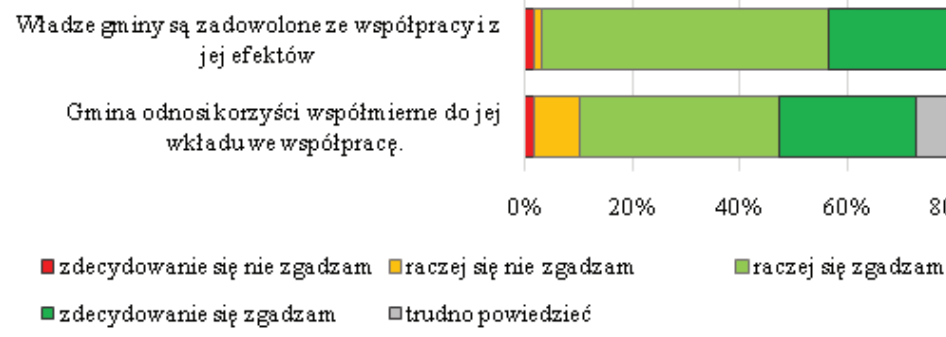

$\square$ zdecydowanie się nie zgadzam $\square$ raczej się nie zgadzam

$\square$ raczej się zgadzam

$\square$ zdecydowanie się zgadzam $\square$ trudno powiedzieć

Źródło: opracowanie własne na podstawie wyników badania ankietowego.

Czy należy zatem wnioskować, że współpraca jest przydatnym narzędziem, umożliwiającym usprawnienie gospodarki odpadami komunalnymi w gminach? Pomimo dominujących pozytywnych ocen respondentów, takie stwierdzenie na tym etapie badań wydaje się zbyt ryzykowne. Ocena efektywności i opłacalności funkcjonowania struktur, w której uczestniczy wiele podmiotów jest bardzo złożonym zjawiskiem $^{33}$. Pomimo istnienia zbiorowego celu, wokół którego zbudowano współdziałanie, każdy z partnerów zachowuje niezależność i indywidualne oczekiwania wobec współpracy. Pozornie niewielkie różnice mogą znacząco wpływać na zadowolenie każdego z nich i dokonywaną przez nich ocenę danej inicjatywy kooperacyjnej. Z tego powodu opinie wyrażone w ankietach przez reprezentantów poszczególnych gmin są bardzo istotne w tego typu badaniach, jednak nie powinny być jedynym źródłem informacji w analizie rzeczywistej opłacalności współdziałania. Chcąc uzyskać pełny obraz, należy uzupełnić je obiektywnymi danymi umożliwiającymi porównanie kosztów i funkcjonowanie gospodarki odpadami w gminach współpracujących i niewspółpracujących ${ }^{34}$.

${ }^{33}$ Zob. E. Klijn, J. Koppenjan, Zarzq̨dzanie publiczne i sieci powiq̨zań. Podstawy podejścia do rządzenia opartego na teorii sieci, „Zarządzanie Publiczne” 2011, nr 2-3 (16-17), s. 137-139.

${ }^{34}$ Autorka artykułu prowadzi obecnie takie badania w ramach przygotowywanej pracy doktorskiej. 
Aleksandra Picej - Potencjał wykorzystania współpracy międzygminnej...

O tym, że ocena opłacalności kooperacji może sprawiać trudności także uczestniczącym w niej samorządom, świadczy stosunek respondentów do stwierdzenia, że reprezentowana przez nich gmina odnosi korzyści współmierne do jej wkładu we współpracę (wykres 4.). Ponad 1/4 ankietowanych wybrała odpowiedź „trudno powiedzieć”, przy czym niemal $2 / 3$ zgodziło się z tą tezą. Nie wiadomo jednak, czy tak duży odsetek pozytywnych odpowiedzi znajduje oparcie w rzetelnej ocenie opłacalności dokonywanej przez gminy czy też jedynie w logicznym osądzie respondentów - jeśli gmina współpracuje, tzn. że jest to opłacalne i przynosi wymierne korzyści.

\section{Podsumowanie}

Choć wstępna analiza uwarunkowań gospodarki odpadami komunalnymi w Polsce wykazała istnienie przesłanek do podjęcia współpracy międzygminnej $\mathrm{w}$ tej dziedzinie, $\mathrm{z}$ ankiet wielkopolskich i kujawsko-pomorskich urzędów gmin wynika, że w rzeczywistości zapotrzebowanie na kooperację jest mniejsze niż zakładano, przystępując do badania. W pewnym zakresie może być to spowodowane powszechnym outsourcingiem odbioru, a często także zagospodarowania odpadów, któremu sprzyja otoczenie prawne i który nierzadko jest traktowany (obok współpracy) jako jedno z rozwiązań problemu niepokrywania się zasięgów funkcjonalnych i granic administracyjnych ${ }^{35}$. Niewykluczone, że zastosowanie tego narzędzia w wielu przypadkach pozwoliło wykształcić efektywny system gospodarki odpadami bez konieczności współdziałania z innymi samorządami.

W gminach, które zdecydowały się na współpracę, najczęściej umotywowana była ona potrzebą spełnienia formalnych wymogów lub chęcią realizacji wspólnej inwestycji, a także próbą obniżenia kosztów i poprawy jakości świadczonych usług, w tym wzmocnienia ochrony środowiska. Udzielone odpowiedzi uwidoczniły dużą rolę regulacji prawnych i decyzji na szczeblu wojewódzkim w kształtowaniu współpracy

${ }^{35}$ G. Bel, X. Fageda, M. Mur, Does Cooperation..., op. cit., s. 85-86. 
w gospodarce odpadami, co wskazuje na to, że zgodnie z przytoczoną klasyfikacją Sullivan i Skelchera, współdziałanie w tej dziedzinie nierzadko jest reakcją na zmiany zewnętrznych uwarunkowań. Jednocześnie służy ono osiąganiu wspólnych celów, w tym korzyści skali. Mniej istotne niż początkowo przypuszczano okazały się motywy dotyczące zwiększenia widoczności samorządów lokalnych i wzmocnienia roli ich opinii w dyskusji na arenie krajowej i regionalnej.

Ocena dotychczasowego współdziałania dokonana przez respondentów była pozytywna, a w większości przypadków zadeklarowano osiągnięcie zakładanych celów współpracy. Największe, ok. 30\% odsetki niespełnionych oczekiwań dotyczyły motywów obniżenia kosztów gospodarki odpadami oraz wzmocnienia ochrony środowiska. Jednocześnie ankieta wykazała, że ocena opłacalności współpracy sprawiła trudność ok. 1/4 respondentów. Potwierdza to złożoność problematyki działań zbiorowych, które powinny być analizowane zarówno w oparciu o indywidualne opinie ich uczestników, jak i obiektywne pomiary efektów. Pomimo że wyniki ankiety oraz analiza uwarunkowań gospodarowania odpadami komunalnymi w Polsce wskazują na istnienie potencjału dla wykorzystania współpracy międzygminnej w tej dziedzinie, dla ostatecznego rozstrzygnięcia o jej opłacalności niezbędne są dalsze badania, w tym porównujące koszty i jakość gospodarki odpadami w gminach współpracujących i niewspółpracujących, najlepiej w co najmniej kilkuletnim okresie. Nie do przecenienia byłby również pogłębione studia przypadków inicjatyw kooperacyjnych, służące zrozumieniu aspektów współdziałania, trudnych do uchwycenia w ramach ankiet, takich jak np. wzajemne relacje między gminami partnerskimi, czy też lokalne uwarunkowania oddziałujące na współpracę.

\section{Bibliografia:}

Bel G., Costas A., Do public sector reforms get rusty?: Local privatization in Spain, „Journal of Policy Reform” 2006, nr 9 (1).

Bel G., Fageda X., Mur M., 2014, Does Cooperation Reduce Service Delivery Costs? Evidence from Residential Solid Waste Services, „Journal of Public Administration Research and Theory" 2014, nr 24. 
Aleksandra Picej - Potencjał wykorzystania wspótpracy międzygminnej...

Bel G., Mur M., 2009, Inter-municipal cooperation, privatization and waste management costs: Evidence from rural municipalities, „Waste Management”, $\mathrm{nr} 29$ (10).

Bel G., Warner M., Inter-municipal cooperation and costs: Expectation and evidence, „Public Administration” 2015, nr 93(1).

Council of Europe, Toolkit Manual Inter-municipal Cooperation, 2010, http:// www.municipal-cooperation.org/images/4/4c/IMC_Toolkit_Manual.pdf [dostęp: 1-07-2017].

Dijkgraaf E., Gradus R.H.J.M., Cost advantage cooperation's larger than private waste factors. „Applied Economics Letters” 2013, nr 20 (7).

Dijkgraaf E., Gradus R.H.J.M., 2014, Waste Management in the Netherlands, [w:] T. Kinnaman, K. Takeuchi (red.), Handbook on Waste Management, Edward Elgar Publishers, Cheltenham 2014.

Furmankiewicz M., Funkcjonalno-przestrzenne sieci współpracy samorzq̨ów lokalnych, „Studia Regionalne i Lokalne” 2002, nr 1 (8).

Hulst R., van Montfort, A. (red.), Inter-municipal Cooperation in Europe, Springer, Dordrecht 2007.

Ilnicki D., Siłka T., 2001, Polska przestrzeń w kontekście nowego podziału administracyjnego [w:] H. Rogacki (red.) Koncepcje teoretyczne i metody badań geografii społeczno-ekonomicznej i gospodarki przestrzennej, Bogucki Wyd. Naukowe, Poznań 2001.

Jerzmański J., Gospodarka odpadami komunalnymi - nowe zasady, „Przegląd Komunalny" 2011, nr 9 (240).

Klijn E., Koppenjan J., Zarządzanie publiczne i sieci powiązań. Podstawy podejścia do rządzenia opartego na teorii sieci, „Zarządzanie Publiczne” 2011, nr 2-3 (16-17).

Kołsut B., Zinstytucjonalizowane sieci współdziałania międzygminnego w Polsce, Bogucki Wyd. Naukowe, Poznań 2015.

Nemec J., Soukopova J., Mikusova Merickova B., Economic Aspects of the Municipal Waste Management: The Czech Republic and Slovakia, „Croatian and Comparative Public Administration" 2015, nr 15 (3).

Sørensen R.J, Does Dispersed Public Ownership Impair Efficiency? The Case of Refuse Collection in Norway, „Public Administration” 2007, nr 85 (4).

Soukopova J., Ochrana F., Klimovsky D., Mikusova Merickova B., Factors Influencing the Efficiency and Effectiveness of Municipal Waste Management Expenditure, „Lex Localis - Journal Of Local Self-Government” 2016, nr 14(3).

Sullivan H., Skelcher C., Working across boundaries: collaboration in public services, Palgrave-MacMillan, Basingstoke 2002. 
Swianiewicz P., Demanded but Difficult: Intermunicipal Cooperation in Central and Eastern Europe, [w:] P. Swianiewicz (red.), Working Together. Intermunicipal Cooperation in Five Central European Countries, Budapest: Open Society Fundations, Budapest 2011.

Swianiewicz P., Gendźwiłł A., Krukowska J., Lackowska M., Picej A., Współpraca międzygminna w Polsce. Zwiq̨zek z rozsądku, Wyd. Naukowe Scholar, Warszawa 2016.

Ustawa z dnia 13 września 1996 r. o utrzymaniu czystości i porządku w gminach, Dz.U. 1996 nr 132 poz. 622, z późn. zm.

Zafra-Gómez J.L., Prior D., Plata-Díaz A.M., López-Hernández A.M., Reducing costs in times of crisis: Delivery forms in small and medium sized local governments' waste management services, „Public Administration” 2013, nr 91 (1). 
